\title{
PENGARUH MODEL PEMBELAJARAN AUDITORY INTELLECTUALLY REPETITION TERHADAP KEMAMPUAN MULTI REPRESENTASI MATEMATIS SISWA SMP
}

\author{
Rika Wahyuni ${ }^{1}$, Nindy Citroresmi. ${ }^{2}$ \\ ${ }^{1}$ Pendidikan Matematika STKIP Singkawang, Jalan STKIP Kelurahan Naram Singkawang Utara \\ Email: rikawahyuni142@gmail.com \\ ${ }^{2}$ Pendidikan Matematika STKIP Singkawang, Jalan STKIP Kelurahan Naram Singkawang Utara \\ Email: Nindy.citroresmi@gmail.com
}

\begin{abstract}
This study aims to determine the effect of the AIR learning model on students' multimathematical representation abilities, student activities and learning motivation. The population of this research is all students of class VIII. Samples were taken by simple random sampling technique. The selected sample consisted of two classes, namely VIIIB as the experimental class and VIIIC as the control class. This research is an experimental research design with Pretest-Postest Control Gruop. The results of the study can be concluded that: (1) There is a difference in the ability of multi mathematical representation of students in the class using the AIR learning model and the class using the direct learning model. (2) The effect of the AIR model is relatively high on the ability of students' multiple mathematical representations; 3) student learning activities as a whole are classified as very active; 4) student motivation is categorized high.
\end{abstract}

Keywords : Auditory Intellectually Repetition, multi representations, student activities, student motivation

\section{PENDAhULUAN}

National Council of Teachers of Mathematics (NCTM, 2000) menetapkan lima standar kemampuan matematis yang harus dimiliki siswa yaitu kemampuan pemecahan masalah (problem solving), kemampuan komunikasi (communication), kemampuan koneksi (connection), kemampuan penalaran (reasoning), dan kemampuan representasi (representation). Pada awalnya standar-standar yang direkomendasikan di dalam NCTM 1989 hanya terdiri dari empat kompetensi dasar yaitu pemecahan masalah, komunikasi, koneksi, dan penalaran, sedangkan representasi masih dipandang sebagai bagian dari komunikasi matematis . Namun, karena disadari bahwa representasi matematis merupakan suatu hal yang selalu muncul ketika orang mempelajari matematika pada semua tingkatan atau level pendidikan, maka dipandang bahwa representasi merupakan suatu komponen yang layak mendapat perhatian serius. Dengan demikian representasi matematis perlu mendapat penekanan dan dimunculkan dalam proses pengajaran matematika di sekolah (Abdullah, 2012).

Gagasan mengenai representasi matematis di Indonesia juga telah dicantumkan dalam tujuan pembelajaran matematika di sekolah dalam Permendiknas No. 23 Tahun 2006 yang 
menyatakan peserta didik memiliki kemampuan mengkomunikasikan gagasan dengan simbol, tabel, diagram, atau media lain untuk memperjelas keadaan atau masalah (Depdiknas, 2007). Selain itu, NCTM (2000) juga mengemukakan bahwa:

Representation is central to the study of mathematics. Students can develop and deepen their understanding of mathematical concepts and relationships as they create, compare, and use various representations. Representations such as physical objects, drawings, charts, graphs, and symbols also help students communicate their thinking.

Kemampuan representasi matematis merupakan kemampuan yang menggunakan berbagai bentuk matematis untuk menjelaskan ide-ide matematis, melakukan translasi, menginetrpretasikan fenomena matematis dengan berbagai bentuk matematis yaitu visual, symbol, dan verbal. Hal ini, sangat memungkinkan bagi peserta didik untuk mencoba berbagai representasi sebagai wujud dari strategi-strateginya dalam menyelesaikan suatu masalah matematis. Penggunaan representasi yang beragam dalam menyelesaikan suatu soal disebut multirepresentasi (Darmastini, 2014). Multi representasi adalah penggunaan representasi yang berbeda-beda (seperti grafik, tabel, persamaan, diagram) pada waktu yang bersamaan (Gyamfi, 2003). Jenis representasi eksternal yang diungkapkan oleh Gyamfi adalah representasi verbal (penulisan dalam bentuk kata-kata), representasi grafikal (grafik kartesius), representasi aljabar atau simbol (ekspresi berupa persamaan yang berhubungan antara dua atau lebih kuantitas), representasi piktorial (diagram atau gambar), representasi tabular (tabel).

Alasan pentingnya multi representasi matematis siswa di dalam pembelajaran yaitu dapat memberi kelancaran siswa dalam membangun suatu konsep yang kuat dan fleksibel serta menyajikan konsep dalam berbagai bentuk representasi matematis, hal ini jelas menunjukkan bahwa multi representasi berperan penting dalam membangun suatu konsep. Menurut Novitasari (2017) ada tiga fungsi utama dari multi representasi, yaitu sebagai pelengkap dalam proses kognitif, membantu membatasi kemungkinan kesalahan interpretasi lain, dan membangun pemahaman konsep dengan lebih mendalam. Selain tiga fungsi utama di atas, multi representasi juga berfungsi untuk menggali perbedaan-perbedaan dalam suatu informasi yang dinyatakan oleh masing- masing interpretasi, hal ini jelas menunjukkan bahwa multi representasi berperan penting dalam membangun suatu konsep

Namun, yang terjadi di lapangan menunjukkan bahwa kemampuan multi representasi matematis siswa kurang dikembangkan dalam proses pembelajaran. Beberapa penelitian yang telah dilakukan menjelaskan mengenai kesalahan-kesalahan yang dilakukan siswa dalam kemampuan multirepresentasi. Penelitian Andromeda, dkk (2017) menunjukkan bahwa terdapat kekeliruan pada representasi yang dibentuk oleh sebagian besar siswa terutama dalam representasi fisis dan matematis di mana kemampuan multirepresentasi siswa yang di peroleh sebesar $41,3 \%$ dari skor maksimal. Rendahnya kemampuan multi representasi matematis siswa juga dialami SMP Negeri 13 Singkawang. Hal ini diperoleh dari hasil wawancara dengan salah satu guru bidang studi Matematika, yang menyatakan bahwa saat siswa diberikan soal cerita yang mengarah kepada indikator kemampuan multirepresentasi masih banyak siswa yang belum bisa merubah masalah soal cerita tersebut ke dalam bentuk gambar maupun simbol matematika.

Rendahnya kemampuan multi representasi matematis siswa dapat dipengaruhi oleh aktivitas dan motivasi belajar siswa di kelas. Berdasarkan hasil observasi dan wawancara dengan salah satu siswa di SMP Negeri 13 Singkawang terlihat bahwa aktivitas dan motivasi siswa masih kurang. Siswa cenderung hanya diam dan asyik dengan kegiatannya sendiri, siswa tidak berani untuk menanyakan materi yang belum dipahami serta tidak berani 
mengeluarkan pendapat-pendapat mereka. Siswa juga tidak semangat dalam pembelajaran dan cepat bosan dalam belajar matematika. Hal ini akan berdampak pada hasil yang kurang memuaskan dan nilai yang didapat tidak sesuai dengan yang diharapkan.

Berdasarkan permasalahan di atas maka diperlukan suatu pembelajaran yang lebih menekankan kemampuan, aktivitas dan motivasi siswa. Menurut Aunurrahman (2010) penggunaan model pembelajaran yang tepat dapat mendorong timbulnya rasa senang siswa terhadap pelajaran, menumbuhkan dan meningkatkan motivasi dalam mengerjakan tugas, memberikan kemudahan bagi siswa untuk memahami pelajaran sehingga memungkinkan siswa mencapai hasil belajar yang lebih baik. Auditory Intellectually Repetition (AIR) adalah salah satu alternatif model pembelajaran yang bisa dipraktekan dalam pembelajaran matematika. Model pembelajaran AIR menganggap bahwa suatu pembelajaran akan efektif jika memperhatikan tiga hal, yaitu Auditory, Intellectually dan Repetition. Auditory berarti indra telinga digunakan dalam belajar dengan cara menyimak, berbicara, presentasi, argumentasi, mengemukakan pendapat, dan menanggapi. Intellectually berarti kemampuan berpikir perlu dilatih melalui latihan bernalar, mencipta, memecahkan masalah, mengkonstruksi, dan menerapkan. Repetition berarti pengulangan diperlukan dalam pembelajaran agar pemahaman lebih mendalam dan lebih luas, peserta didik perlu dilatih melalui pengerjaan soal, pemberian tugas atau kuis (Maulana, 2012)

Dengan demikian model pembelajaran Auditory Intellectually Repetition (AIR) diharapkan dapat memberikan pengaruh positif terhadap kemampuan multi representasi siswa di SMP Negeri 13 Singkawang karena dalam proses pembelajaran dengan model Auditory Intellectually Repetition (AIR) siswa dituntut untuk dapat menggunakan alat indera nya untuk membangun sendiri pengetahuannya melalui diskusi, presentasi dan pengulangan (kuis) untuk memperdalam dan memperluas pemahaman siswa. Hal ini sesuai dengan kemampuan multi representasi matematis siswa dimana siswa diharapkan mampu mengemukakan ide tidak hanya melalui lisan, tetapi juga dalam bentuk gambar (visual), katakata (verbal), dan ekspresi matematis. Berdasarkan uraian di atas, maka judul yang di pilih pada penelitian ini adalah "Pengaruh Model Pembelajaran Auditory Intellectually and Repetition (AIR) Terhadap Kemampuan Multi Representasi Matematis Siswa.

\section{METODE PENELITIAN}

Jenis penelitian ini adalah jenis penelitian kuantitatif dengan metode eksperimen. Desain penelitian yang digunakan dalam penelitian ini adalah quasi-eksperimental design dengan rancangan nonequivalent posttest-only control group design. Terdapat dua kelas dalam penelitian ini yaitu kelas pertama disebut sebagai kelas eksperimen dan kelas kedua disebut sebagai kelas kontrol. Adapun sekolah yang menjadi tempat penelitian adalah di SMP Negeri 13 Singkawang kelas VIII yang beralamat di Jalan Wonosari Kelurahan Sekip Baru Kecamatan Singkawang Tengah. Populasi dalam penelitian ini adalah seluruh kelas VIII SMP Negeri 13 Singkawang yang terdiri dari empat kelas yaitu VIII A, VIII B, VIII C, VIII $\mathrm{D}$ yang berjumlah 88 siswa. Teknik pengambilan sampel pada penelitian ini dengan menggunakan teknik simple random sampling. Adapun yang menjadi kelas eksperimen adalah kelas VIIIB dan kelas kontrol adalah kelas VIIIC.Teknik analisis data yang digunakan dalam penelitian ini adalah analisis kuantitatif dengan statistika. Dalam penelitian ini akan diperoleh data kuantitatif sehingga untuk menganalisis data didapatkan dari pemberian tes hasil belajar, pengamatan menggunakan lembar aktivitas dan motivasi menggunakan lembar angket akan dilakukan teknik statistik. 
Rika Wahyuni ${ }^{1}$, Nindy Citroresmi. ${ }^{2}$

\section{HASIL DAN PEMBAHASAN}

a. Kemampuan Multi Representasi Matematis Siswa

Hasil pengumpulan data selama penelitian diperoleh data hasil posttest (berupa skor) dari kelas yang diajarkan dengan model pembelajaran Auditory Intellectually Repetition (AIR) untuk kelas eksperimen dan pembelajaran langsung untuk kelas kontrol terhadap kemampuan multi representasi matematis siswa pada materi aljabar. Adapun soal posttest yang diberikan berbentuk tes kemampuan multi representasi matematis sebanyak tiga soal dengan tiga indikator yaitu: 1) menggunakan representasi visual untuk menyelesaikan masalah; 2) menggunakan representasi simbol untuk menyelesaikan masalah; 3) menggunakan representasi verbal untuk menyelesaikan masalah.

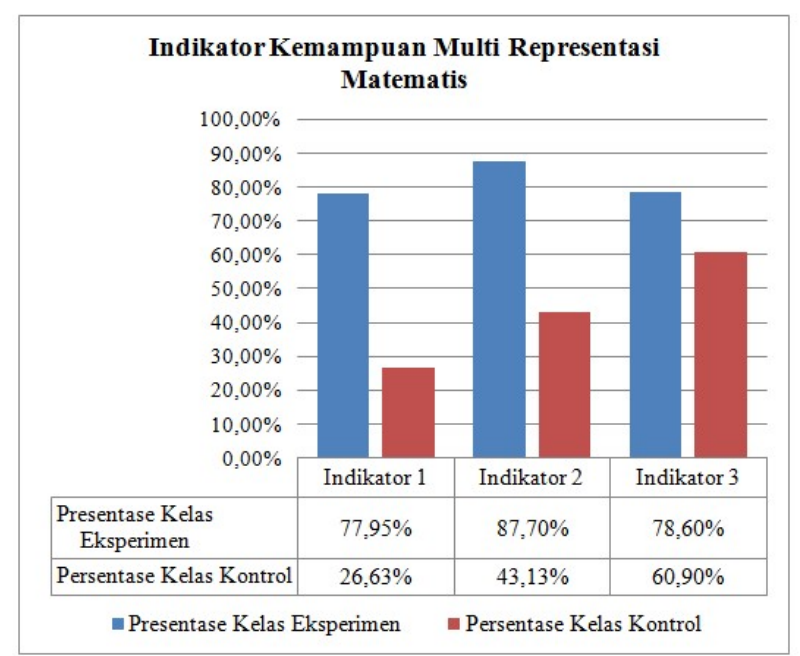

\section{Gambar 1. Diagram Batang Persentase Kemampuan Multi Representasi Matematis Siswa}

Gambar 1 menunjukkan bahwa rata-rata indikator kemampuan multi representasi matematis siswa kelas eksperimen lebih tinggi daripada rata-rata indikator kemampuan multi representasi matematis siswa kelas kontrol. Selanjutnya secara keseluruhan rata-rata hasil posttest kemampuan multi representasi siswa kelas eksperimen dan kelas kontrol dapat dilihat pada gambar diagram batang 2 sebagai berikut:

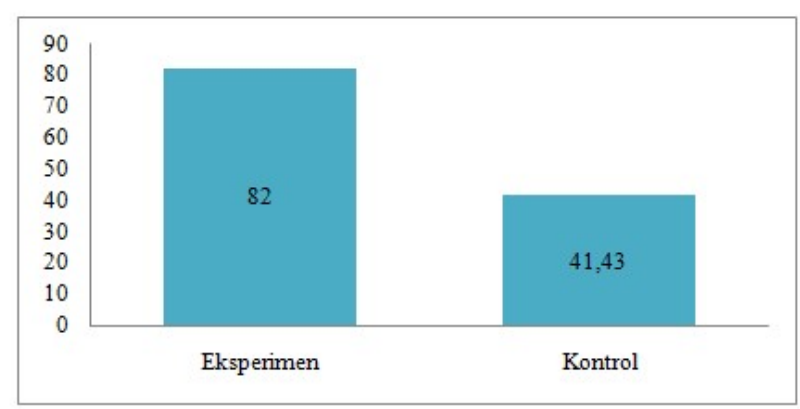

Gambar 2. Diagram Batang Nilai Rata-ratal Posttest Kelas Ekperimen dan Kelas Kontrol 
Gambar 1 dan 2 menunjukan bahwa secara deskriptif rata-rata posttest antara kelas kontrol dan kelas eksperimen berbeda, namun secara inferensial nilai tersebut belum tentu memiliki perbedaan yang signifikan. Untuk melihat perbedaan antara kelas yang menggunakan model pembelajaran Auditory Intellectually Repetition (AIR) dengan kelas yang menggunakan model pembelajaran langsung (kelas kontrol) maka menggunakan uji-t dua sampel independen. Namun sebelumnya dilakukan uji normalitas dan uji homogenitas. Berdasarkan hasil perhitungan, untuk data posttest kelas eksperimen dan kontrol disajikan ada Tabel I sebagai berikut:

TABEL I

REKAPITULASI PERHITUNGAN UJI NORMALITAS KELAS EKSPERIMEN DAN KONTROL

\begin{tabular}{|c|c|c|c|c|}
\hline $\begin{array}{c}{[1]} \\
\text { Kelompok }\end{array}$ & $\mathrm{N}$ & $\begin{array}{c}x^{2} \\
\text { Hitung }\end{array}$ & $\begin{array}{c}x^{2} \\
\text { Tabel }\end{array}$ & Kesimpulan \\
\hline Eksperimen & 21 & 12,414 & 9,488 & Data Berdistribusi Tidak Normal \\
\hline Kontrol & 23 & 22,483 & 9,488 & Data Berdistribusi tidak Normal \\
\hline
\end{tabular}

Tabel I menunjukkam bahwa data posttest kelas eksperimen dan kelas kontol berdistribusi tidak normal. Maka untuk mengetahui perbedaan penggunaan model pembelajaran AIR dan model pembelajaran langsung peneliti menggunakan uji Man Whitney $U$-Test. Adapun rekapitulasi hasil perhitungan perbedaan penggunaan model pembelajaran $A I R$ dan model pembelajaran langsung terhadap kemampuan multi representasi matematis siswa dapat dilihat pada Tabel II berikut.

TABEL II

REKAPITULASI PERHITUNGAN UJi MAN WhitNey U-TEST

\begin{tabular}{ccccccc} 
Keterangan & $\boldsymbol{n}_{\mathbf{1}}$ & $\boldsymbol{n}_{\mathbf{2}}$ & $\mathbf{U}_{\mathbf{1}}$ & $\mathbf{U}_{\mathbf{2}}$ & $\mathbf{E}(\mathbf{U})$ & $\operatorname{Var}(\mathbf{U})$ \\
\hline Skor & 21 & 23 & 0,5 & 482,5 & 104,25 & 1811,25 \\
$\mathbf{Z}_{\text {hitung }}$ & & \multicolumn{5}{c}{$-5,66$} \\
$\mathbf{- Z}_{\text {tabel }}$ & \multicolumn{5}{c}{$-1,96$} \\
\hline
\end{tabular}

Tabel II di atas terlihat bahwa nilai $Z_{\text {hitung }}=-5,66$. Berdasarkan kriteria pengujian maka penggunaan model pembelajaran $A I R$ dan model pembelajaran langsung terhadap kemampuan multi representasi matematis siswa dikatakan memiliki perbedaan apabila $Z_{\text {hitung }}$ $<-Z_{\text {tabel }}$ atau $\mathrm{H}_{\mathrm{o}}$ ditolak, sebaliknya dikatakan tidak ada perbedaan penggunaan model pembelajaran $A I R$ dan model pembelajaran langsung terhadap kemampuan multi representasi matematis siswa apabila $-Z_{\text {tabel }} \leq Z_{\text {hitung }} \leq Z_{\text {tabel }}$ atau $H_{o}$ diterima. Diketahui $Z_{\text {hitung }}<-Z_{\text {tabel }}$ atau $-5,66<-1,96$, maka Ho ditolak. Dapat disimpulkan bahwa terdapat perbedaan penggunaan model pembelajaran $A I R$ dan model pembelajaran langsung terhadap kemampuan multi representasi matematis siswa pada materi aljabar kelas VIII SMP Negeri 13 Singkawang.

Perbedaan kemampuan multi representasi matematis antara kelas eksperimen dan kelas kontrol disebabkan pada proses pembelajaran dengan model $A I R$ memiliki fase-fase yang membuat siswa lebih aktif dan lebih dapat memahami materi. Guru tidak sekadar memberikan pengetahuan kepada siswa, melainkan memfasilitasi siswa untuk membangun pengetahuannya sendiri sehingga siswa memiliki pemahaman yang lebih mantap terhadap materi aljabar.

Selanjutnya untuk melihat seberapa besar pengaruh model pembelajaran AIR terhadap kemampuan multi representasi matematis siswa, maka digunakan rumus Effect Size. Adapun hasil perhitungan Effect Size dapat dilihat pada Tabel III sebagai berikut. 
Pengaruh Model Pembelajaran Auditory Intellectually Repetition Terhadap Kemampuan Multi Representasi Matematis Siswa SMP

Rika Wahyuni ${ }^{1}$, Nindy Citroresmi.P ${ }^{2}$

TABEL III

REKAPITULASI HASIL UJI EFFECT SIZE

\begin{tabular}{|c|c|c|c|c|}
\hline Kelas & Nilai Rata-rata & $\begin{array}{c}\text { Standar Deviasi } \\
\text { Gabungan }\end{array}$ & $E S$ & Kriteria \\
\hline Eksperimen & 82,00 & 10,47 & 3,87 & Tinggi \\
\hline Kontrol & 41,43 & & & \\
\hline
\end{tabular}

Tabel III menunjukkan bahwa hasil perhitungan Effect Size $=3,87$ dengan kriteria tinggi karena 3,87 berada pada $E S \geq 0,8$. Ini berarti model pembelajaran AIR memberikan pengaruh terhadap kemampuan multi representasi matematis siswa yaitu sebesar 3,87 yang masuk pada kriteria tinggi.

Pengaruh model pembelajaran AIR yang tinggi terhadap kemampuan multi representasi matematis siswa dikarenakan model pembelajaan $A I R$ tersebut dirancang untuk mengoptimalkan alat indera siswa dalam menyerap materi pembelajaran yang disampaikan. Sedangkan pada kelas kontrol, kegiatan pembelajaran yang dilakukan cendrung monoton meskipun guru lebih mudah dalam melakukan pengelolaan kelas. Pembelajaran yang membosankan akan membuat siswa kurang tertarik untuk pembelajaran yang berikutnya sehingga hasil belajar yang dicapai belum optimal. Salah satu kelebihan model pembelajaran AIR yang diungkapkan oleh Shoimin (2014) adalah siswa dengan kemampuan rendah dapat merespon permasalahan dengan cara mereka sendiri. Hal ini sesuai dengan kemampuan multi representasi matematis siswa dimana siswa dapat menyampaikan ide atau gagasan matematika yang dipelajari tidak hanya melalui lisan, tetapi dengan berbagai cara seperti gambar (visual), simbol (ekspresi matematis) dan kata-kata (verbal) menurut dirinya sendiri.

\section{b. Aktivitas Belajar Siswa}

Lembar observasi digunakan untuk mengetahui aktivitas siswa selama mengikuti pembelajaran dengan menggunakan model pembelajaran AIR. Pengamatan dilakukan selama dua kali pertemuan dengan 3 orang pengamat, persentase hasil pengamatan aktivitas siswa selama dua pertemuan disajikan dalam tabel IV sebagai berikut.

TABEL IV

Rekapitulasi Persentase Pengamatan Aktivitas Siswa Pertemuan Pertama dan KEDUA

\begin{tabular}{ccccc}
\hline No & Kategori & Pertemuan & Pertemuan & Rata-rata \\
& Pengamatan & $\mathbf{1}$ & $\mathbf{2}$ & \\
\hline 1 & VisualActivities & $86,24 \%$ & $80,95 \%$ & \\
2 & Oral Activities & $68,25 \%$ & $66,14 \%$ & \\
3 & ListeningActivities & $80,95 \%$ & $80,42 \%$ & $\mathbf{8 0 , 5 5 \%}$ \\
4 & Writing Activities & $89,68 \%$ & $86,51 \%$ & \\
5 & DrawingActivities & $98,41 \%$ & $93,41 \%$ & \\
& Jumlah & $423,53 \%$ & $407,43 \%$ & \\
& Rata-rata & $82,01 \%$ & $79,10 \%$ & \\
& Kriteria & & Sangat Aktif & \\
\hline
\end{tabular}

Tabel IV menunujukkan bahwa persentase rata-rata aktivitas pada pertemuan pertama dan kedua data persentase aktivitas siswa diperoleh rata-rata dari lima kategori pengamatan, dua kali pertemuan dan tiga orang pengamat yaitu sebesar $80,55 \%$. Hal ini menunjukkan 
bahwa aktivitas siswa selama pembelajaran dengan model $A I R$ berlangsung berada pada kategori sangat aktif. Berdasarkan analisis data hasil pengamatan aktivitas siswa diperoleh bahwa aktivitas siswa setiap indikator dalam kategori aktif. Hal ini disebabkan pembelajaran menggunakan model pembelajaran AIR mampu membuat siswa aktif selama proses pembelajaran berlangsung.

\section{c. Motivasi Belajar Siswa}

Angket motivasi belajar siswa dalam penelitian ini merupakan angket yang hanya diberikan kepada siswa kelas eksperimen untuk mengetahui seberapa besar motivasi siswa dengan diterapkan model pembelajaran AIR. Angket motivasi belajar tersebut merupakan angket tertutup dan siswa hanya memilih satu jawaban dari 5 pilihan yang diberikan (sangat setuju, setuju, ragu-ragu, tidak setuju dan sangat tidak setuju) yang telah disediakan. Angket motivasi yang digunakan berupa pernyataan positif dan pernyataan negatif yang berjumlah 20 pernyataan dan terdiri dari 5 indikator motivasi belajar.

Hasil perhitungan rata-rata angket motivasi belajar siswa pada pernyataan positif pada kelas eksperimen dapat dilihat pada Tabel V sebagai berikut.

TABEL V

REKAPITULASI HASIL ANGKET MOTIVASI SISWA UNTUK PERNYATAAN POSITIF

\begin{tabular}{|c|c|c|c|c|c|c|c|}
\hline \multirow{2}{*}{ Indikator } & \multicolumn{4}{|c|}{ Pilihan } & \multicolumn{2}{|r|}{ Rata-rata } & \multirow[t]{2}{*}{ Kriteria } \\
\hline & SS & $\mathbf{S}$ & $\mathbf{R R}$ & TS & STS & & \\
\hline $\begin{array}{l}\text { Adanya dorongan dan kebutuhan } \\
\text { dalam belajar }\end{array}$ & 80 & 72 & 18 & 4 & 0 & 4,14 & Tinggi \\
\hline $\begin{array}{l}\text { Menunjukan perhatian dan minat } \\
\text { terhadap tugas-tugas yang } \\
\text { diberikan }\end{array}$ & 140 & 128 & 6 & 0 & 1 & 4,37 & $\begin{array}{l}\text { Sangat } \\
\text { Tinggi }\end{array}$ \\
\hline Tekun menghadapi tugas & 65 & 56 & 33 & 6 & 1 & 3,83 & Tinggi \\
\hline Ulet menghadapi kesulitan & 95 & 20 & 12 & 26 & 1 & 3,67 & Tinggi \\
\hline $\begin{array}{l}\text { Adanya hasrat dan keinginan } \\
\text { berhasil }\end{array}$ & 150 & 108 & 18 & 0 & 0 & 4,38 & $\begin{array}{l}\text { Sangat } \\
\text { Tinggi }\end{array}$ \\
\hline \multicolumn{5}{|c|}{ Rata-Rata Keseluruhan } & \multicolumn{2}{|r|}{4,07} & Tinggi \\
\hline
\end{tabular}

Tabel $\mathrm{V}$ menunjukkan bahwa rata-rata motivasi belajar siswa untuk pernyataan positif dari kelima indikator tersebut secara keseluruhan memiliki kriteria tinggi dengan nilai ratarata keseluruhan 4,35. Selanjutnya untuk hasil perhitungan rata-rata angket motivasi belajar siswa pernyataan negatif pada kelas eksperimen dapat dilihat pada Tabel VI berikut.

TABEL VI

ReKAPITUlasi Hasil ANGKet MotiVASI SisWa UNTUK PERNYATAAN NEGATIF

\begin{tabular}{|c|c|c|c|c|c|c|c|}
\hline \multirow[t]{2}{*}{ Indikator } & \multicolumn{4}{|c|}{ Pilihan } & \multicolumn{2}{|c|}{ Rata-rata } & \multirow[t]{2}{*}{ Kriteria } \\
\hline & SS & $\mathbf{S}$ & $\mathbf{R R}$ & TS & STS & & \\
\hline $\begin{array}{l}\text { Adanya dorongan dan kebutuhan } \\
\text { dalam belajar }\end{array}$ & 3 & 6 & 3 & 60 & 100 & 4,1 & Tinggi \\
\hline $\begin{array}{l}\text { Menunjukan perhatian dan minat } \\
\text { terhadap tugas-tugas yang diberikan }\end{array}$ & 2 & 8 & 30 & 32 & 90 & 3,86 & Tinggi \\
\hline Tekun menghadapi tugas & 2 & 4 & 6 & 36 & 30 & 3,71 & Tinggi \\
\hline
\end{tabular}


Pengaruh Model Pembelajaran Auditory Intellectually Repetition Terhadap Kemampuan Multi Representasi Matematis Siswa SMP

Rika Wahyuni ${ }^{1}$, Nindy Citroresmi.P ${ }^{2}$

\begin{tabular}{|c|c|c|c|c|c|c|c|}
\hline Ulet menghadapi kesulitan & 2 & 10 & 36 & 56 & 45 & 3,55 & Tinggi \\
\hline Adanya hasrat dan keinginan berhasil & 1 & 4 & 3 & 40 & 35 & 3,95 & Tinggi \\
\hline \multicolumn{6}{|c|}{ Rata-Rata Keseluruhan } & 3,83 & Tinggi \\
\hline
\end{tabular}

Tabel VI menunjukkan bahwa rata-rata motivasi belajar siswa untuk pernyataan negatif dari kelima indikator tersebut secara keseluruhan memiliki kriteria tinggi dengan nilai rata-rata keseluruhan 3,83 . Secara keseluruhan rata-rata motivasi belajar siswa baik dari pernyataan positif dan pernyataan negatif dapat dilihat pada Tabel VII berikut ini.

TABEL VII

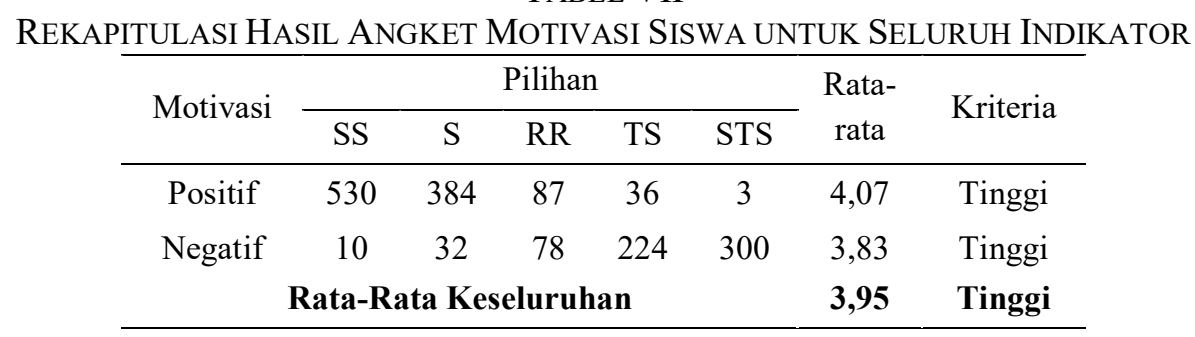

Tabel VII menunjukkan bahwa rata-rata motivasi belajar siswa untuk pernyataan positif dan negatif pada semua indikator berada pada kriteria tinggi dengan jumlah 21 siswa menghasilkan rata-rata keseluruhan siswa adalah 3,95 dengan kriteria tinggi karena berada pada kisaran $3,4<\bar{X} \leq 4,2$.

Motivasi diperlukan untuk mengarahkan seseorang agar melakukan suatu tindakan. Shoimin (2014) menyatakan bahwa satu diantara kelebihan dari model pembelajaran AIR adalah siswa secara intrinsik termotivasi untuk memberikan bukti atau penjelasan. Tingginya motivasi belajar siswa kelas eksperimen pada penelitian ini dikarenakan pada model pembelajaran $A I R$, siswa tidak langsung diberikan hasil akhir dari penyelesaian, melainkan siswa dilatih untuk belajar menyelesaikan masalah dengan cara mereka sendiri melalui diskusi bersama teman sekelompoknya dengan bantuan guru sehingga menimbulkan keingintahuan mereka untuk bisa menyelesaikan masalah yang secara tidak langsung memotivasi keinginan siswa untuk belajar.

\section{KESIMPULAN}

Berdasarkan hasil pengelolaan data hasil penelitian dan pembahasan secara umum dapat disimpulkan bahwa model pembelajaran Auditory Intellectually Repetition (AIR) dapat memberikan pengaruh yang tinggi terhadap kemampuan multi representasi matematis pada materi aljabar kelas VIII SMP Negeri 13 Singkawang. Sesuai dengan sub-sub rumusan masalah penelitian, secara khusus dapat disimpulkan hal-hal sebagai berikut.

a. Terdapat perbedaan kemampuan multi representasi matematis antara siswa yang mendapatkan model pembelajaran Auditory Intellectually Repetition (AIR) dengan siswa yang mendapatkan model pembelajaran langsung pada materi aljabar kelas VIII SMP Negeri 13 Singkawang.

b. Model pembelajaran Auditory Intellectually Repetition (AIR) memberikan pengaruh tinggi terhadap kemampuan multi representasi matematis siswa pada materi aljabar kelas VIII SMP Negeri 13 Singkawang. 
c. Aktivitas belajar siswa selama pembelajaran menggunakan model pembelajaran Auditory Intellectually Repetition (AIR) tergolong pada kriteria sangat aktif.

d. Motivasi belajar siswa tergolong tinggi terhadap model pembelajaran Auditory Intellectually Repetition (AIR) .

\section{e. REFERENSI}

Abdullah. (2012). Peningkatan Kemampuan Representasi Matematika Siswa SMP Melalui Pembelajaran Kontekstual yang Terintegrasi dengan Soft Skill. Prosiding Pendidikan Matematika FMIPA Universitas Negeri Yogyakarta.

Aunurrahman. (2010). Belajar dan Pembelajaran. Bandung: Alfabeta

B Andromeda. (2017). Analisis Kemamuan Multirepresentasi Siswa Pada Konsep-Konsep Gaya di Kelas X SMA Negeri 3 Pontianak. Jurnal Pendidikan dan Pembelajaran.Vol.6 No 10, 1-16

Darmastini, D.P., Rosyidi, A.H. (2014). Multi Representasi Siswa SMP dalam Menyelesaikan Soal Terbuka Matematika Ditinjau Dari Perbedaan Gender. MATHEdunesa Jurnal Ilmiah Pendidikan Matematika. Vol.1. No 3, 56-63.

Depdiknas. (2007). Kajian Kebijakan Kurikulum Mata Pelajaran Matematika. Jakarta: Depdiknas Badan Penelitian dan Pengembangan Pusat Kurikulum

Gyamfi, Kwaku. (2003). External Multiple Representations in Mathematics Teaching. Thesis. North Carolina State University.

Maulana, A. (2012). Model Pembelajaran AIR Untuk Meningkatkan Kemampuan Komunikasi Matematika Siswa. Jurnal FMIPA UPI.

National Council of Teacher of Mathematics (NCTM). (2000). Principles and Standars for School Mathematics. Virginia: Reston.

National Council of Teachers of Mathematic (1989). Curiculum and Evaluation Student for School Mathematic. Reston, VA:NCTM.

Novitasari. (2017). Analisis Kemampuan Multi Representasi Matematis Berdasarkan Kemampuan Awal Matematis Mahasiswa. Jurnal Pendidikan Matematika. Vol. 2. No.1, 1-11

Shoimin, Aris. (2014). Model Pembelajaran Inovatif dalam Kurikulum 2013. Yogyakarta: Ar-ruzz Media 